\title{
Aboveground Biomass Accumulation in a Tropical Wet Forest in Nicaragua Following a Catastrophic Hurricane Disturbance ${ }^{1}$
}

\author{
Joseph Mascaro ${ }^{2,6}$, Ivette Perfecto ${ }^{2}$, Oton Barros ${ }^{2}$, Douglas H. Boucher ${ }^{3}$, Iñigo Granzow de la Cerda ${ }^{4}$, Javier Ruiz ${ }^{4,5}$, and \\ John Vandermeer 2,4 \\ ${ }^{2}$ School of Natural Resources and Environment, University of Michigan, Ann Arbor, Michigan 48109, U.S.A. \\ ${ }^{3}$ Department of Biology, Hood College, Frederick, Maryland 21701, U.S.A. \\ ${ }^{4}$ Department of Biology, University of Michigan, Ann Arbor, Michigan 48109, U.S.A. \\ ${ }^{5}$ Universidades de las Regiones Autonomas de la Costa Atlantica de Nicaragua, Bluefields, Nicaragua
}

\begin{abstract}
Among their effects on forest structure and carbon dynamics, hurricanes frequently create large-scale canopy gaps that promote secondary growth. To measure the accumulation of aboveground biomass (AGBM) in a hurricane damaged forest, we established permanent plots 4 mo after the landfall of Hurricane Joan on the Atlantic coast of Nicaragua in October 1988. We quantified AGBM accumulation in these plots by correlating diameter measurements to AGBM values using a published allometric regression equation for tropical wet forests. In the first measurement year following the storm, AGBM in hurricane-affected plots was quite variable, ranging from 26 to $153 \mathrm{Mg} / \mathrm{ha}$, with a mean of $78( \pm 15) \mathrm{Mg} / \mathrm{ha}$. AGBM was substantially lower than in two control plots several kilometers outside the hurricane's path (331 $\pm 15 \mathrm{Mg} / \mathrm{ha})$. Biomass accumulation was slow $(5.36 \pm 0.74 \mathrm{Mg} / \mathrm{ha} / \mathrm{yr})$, relative to previous studies of forest regeneration following another hurricane (Hugo) and agricultural activity. We suggest that large-scale, homogenous canopy damage caused by Hurricane Joan impeded the dispersal and establishment of pioneer trees and led to a secondary forest dominated by late successional species that resprouted and survived the disturbance. With the relatively slow rate of biomass accumulation, any tightening in disturbance interval could reduce the maximum capacity of the living biomass to store carbon.
\end{abstract}

\section{RESUMEN}

Los huracanes pueden afectar la estructura y dinámica de carbono de los bosques mediante la formación de grandes aperturas del dosel, las cuales estimulan el crecimiento de vegetación secundaria. Para medir la acumulación de biomasa sobre el suelo en un bosque afectado por un huracán, establecimos parcelas permanentes cuatro meses después del paso del huracán Juana en la Costa Atlántica de Nicaragua en 1988. Cuantificamos la acumulación de biomasa sobre el suelo mediante el uso de ecuaciones de regresión alométrica desarrolladas con datos de diámetro y biomasa de árboles de bosques humedo trópicales. En el primer año después del huracán, la biomasa en las parcelas dentro del área afectada por el huracán fue muy variable, con un ámbito de $26-153 \mathrm{Mg} / \mathrm{ha}$, con un promedio de 78 ( \pm 15 ) Mg/ha. Se estimó una biomasa de aproximadamente $331( \pm 15) \mathrm{Mg} / \mathrm{ha}$ en dos parcelas de control a varios kilómetros del área afectada por el huracán. La acumulación de biomasa fue lenta $(5.36 \pm 0.74 \mathrm{Mg} / \mathrm{ha} / \mathrm{yr})$ en las parcelas afectadas en comparación a reportes de regeneración despues de otro huracán (Hugo) o posterior a uso agrícola. Estos resultados sugieren que el impacto extensivo y homogéneo del huracán Juana impidio la dispersión y establecimiento de especies pioneras, llevando a la formación de un bosque secundario compuesto por especies de sucesión tardía que rebrotaron y sobrevivieron al impacto del huracán. La baja tasa de acumulación de la biomasa, sugiere que un incremento en la frecuencia de disturbios podría reducir la capacidad máxima del bosque de almacenar carbono en la biomasa viva.

Key words: aboveground biomass; allometry; disturbance; hurricane, Nicaragua; secondary forest.

NORTH ATLANTIC HURricanes ARE ONE OF THE MOST IMPORTANT DISTURBANCES affecting tropical forests in the Caribbean and Central America (Belt 1888, Vandermeer et al. 1990, Brokaw \& Walker 1991, Walker et al. 1991, Yih et al. 1991, Boose et al. 1994, Zimmerman et al. 1996, Lugo 2000, Dale et al. 2001). These storms are a natural part of the forest ecosystem, causing a recurring oscillation between sudden damage and gradual regrowth. Observations at the Luquillo Long-Term Ecological Research site on Puerto Rico indicate that prolonged disturbance by hurricanes fundamentally alters the ecology, physiognomy, and carbon dynamics of tropical forests over long time scales (Brokaw \& Walker 1991, Walker et al. 1991, Zimmerman et al. 1995, Lugo \& Scatena 1996, Lugo $2000)$. In the short term, the flux of carbon dioxide $\left(\mathrm{CO}_{2}\right)$ between

${ }^{1}$ Received 29 March 2004; revision accepted 30 January 2005.

${ }^{6}$ Corresponding author. Current address: University of Wisconsin, Milwaukee, Department of Biology, Lapham Hall, 3209 N. Maryland Ave., Milwaukee, WI 53201; e-mail: jmascaro@uwm.edu tropical forests and the atmosphere is extremely sensitive to perturbation, and hurricanes can have an immediate and overwhelming effect on the carbon balance of a forest (Brown \& Lugo 1982, Lugo 2000, Breshears \& Allen 2002, McNulty 2002). Hurricane Joan, for example, leveled approximately 500,000 ha of primary forest in a matter of hours, a rate not exceeded by the direst estimates of deforestation for the globe (Yih et al. 1991, Houghton et al. 2000). Changes in forest structure following Joan may have also caused increased susceptibility to fires induced by the 1997-1998 El Niño Southern Oscillation (ENSO), as well as accelerated agricultural activity.

It now appears that many disturbance regimes might be altered as a result of anthropogenic climate forcing, and atmospheric models have suggested a potential for increased hurricane frequency and intensity (Emanuel 1987, Gray 1990, Walsh \& Pittock 1998, Dale et al. 2001). Recent empirical trends (1995-2000) for the North Atlantic show a potentially lasting increase in hurricane frequency, 
particularly for the Caribbean; however, this trend cannot be explained by anthropogenic forcing (Goldenberg et al. 2001, see also Easterling et al. 2000). Irrespective of the cause, changes in hurricane frequency and intensity would substantially alter tropical forest dynamics, arresting tree growth and regeneration, and accelerating nutrient and carbon cycling (Lugo 2000).

HURRICANES AND BIOMASS.- - Hurricanes have two key effects on the aboveground biomass (AGBM) of a forest. First, storm damage in the short run causes a net loss of live AGBM, converting it to coarse woody debris at the forest floor that immediately begins to decompose (Vandermeer et al. 1990, Brokaw \& Walker 1991, Zimmerman et al. 1995, Scatena et al. 1996, Lugo 2000). McNulty (2002) reported that a single hurricane could convert 10 percent of the total annual carbon sequestered by U.S. forests into downed biomass. Whether or not this material represents a source or sink of $\mathrm{CO}_{2}$ is uncertain and probably varies considerably with landscape heterogeneity. Lugo (2000) noted that landslides and mudflows associated with hurricanes may bury the material, slowing decomposition, or that the material could be exported to anoxic marine environments by large runoff events. If left to decompose, however, canopy material felled by hurricanes represents a substantial source of $\mathrm{CO}_{2}$.

Second, hurricanes create large-scale canopy gaps, encouraging secondary forest growth that results in a gradual accumulation of biomass (Vandermeer et al. 1990, Brokaw \& Walker 1991, Zimmerman et al. 1995, Scatena et al. 1996, Lugo 2000). With the increasing abundance of secondary forests worldwide, and the possibility of utilizing them as part of a management strategy to capture atmospheric $\mathrm{CO}_{2}$ (reviewed by Hoffert et al. 2002), considerable research has been aimed at biomass accumulation in these forest types (Brown \& Lugo 1990, Vitousek 1991, Fearnside \& Guimaraes 1996, Alves et al. 1997, Hughes et al. 1999, Cairns et al. 2000, Johnson et al. 2000, Silver et al. 2000, Chave et al. 2001, Rudel 2001). For the most part, however, these studies are concerned with secondary growth following agricultural abandonment, and there is some concern that the carbon dynamics following natural disturbances are being ignored (Dale et al. 2001, Breshears \& Allen 2002).

Hurricane Joan struck the Atlantic Coast of Nicaragua on 22 October 1988, completely destroying the forest canopy over an area of 500,000 ha (Vandermeer et al. 1990, Yih et al. 1991). The $250 \mathrm{~km} / \mathrm{h}$ wind gusts of the category IV storm snapped or uprooted 80 percent of the trees, and completely defoliated those that remained standing (Yih et al. 1991). The return frequency of a hurricane of comparable intensity was estimated at $100 \mathrm{yr}$ for the region (Boucher 1992). Unlike Hurricane Hugo (see Brokaw \& Grear 1991), after which destruction was patchy and whole sections of primary forest survived unscathed, the damage following Joan was relatively homogenous. Forest regeneration followed the direct regeneration hypothesis; it was dominated by nonpioneer seedlings and saplings that survived the hurricane, and sprouting from snapped trees (Vandermeer et al. 1995, 1996, 2000). This pattern of regeneration was fundamentally different from the processes operating in the Luquillo Mountains in Puerto Rico after the impact of Hurricane Hugo (Scatena et al. 1996, Lugo 2000). Direct regeneration of the forest in the aftermath of Hurricane Joan has been the subject of intensive, long-term studies, and more detailed information about the ecology of the recovery is available elsewhere (Vandermeer et al. 1990, 1995, 1996, 2000; Yih et al. 1991; Vandermeer \& Perfecto 1995; Granzow de la Cerda et al. 1997; Boucher et al. 2001; Vandermeer \& Granzow de la Cerda 2004). In this study, we describe the nature and rate of AGBM recovery following extensive damage by Hurricane Joan, and compare this rate to that of forests recovering from Hurricane Hugo, as well as agricultural abandonment.

\section{METHODS}

STUDY AREA AND SAMPLING.-We conducted this study in a lowland Neotropical rain forest in the region surrounding Bluefields, on the Atlantic coast of southern Nicaragua. The vegetation is highly species-rich, with a relatively low canopy and a palm-dominated understory, and is classified as tropical wet forest in the Holdridge life zone system (Holdridge et al. 1971). The region averages $30 \mathrm{~m}$ in elevation, ranging from 0 to $60 \mathrm{~m}$, and receives $4000-4800 \mathrm{~mm}$ of rainfall per year, with March and April receiving only $60 \mathrm{~mm}$ (Incer 1973, Blair 2002). Soils are residual, lava-derived ultisols, relatively rich in organic matter, carbon, and phosphorus (Blair 2002). For more detailed information concerning the geology, climate, flora, and fauna of Nicaragua see Incer (1973) and Hollowell (2001).

Following the use of temporary plots to collect data in February 1989 , we permanently established six $100 \times 10 \mathrm{~m}(0.1 \mathrm{ha})$ plots in 1990 throughout the area damaged by Hurricane Joan (three at La Bodega and three at La Fonseca; see maps in Vandermeer $e$ t al. 1990, 2000 and Yih et al. 1991). Four of these plots were eventually abandoned due to agricultural activity and recurring fires associated with the 1997-1998 ENSO event (Table 1). To substitute these losses, we established six additional $50 \times 30 \mathrm{~m}(0.15 \mathrm{ha})$ plots at alternate sites (two at La Bodega in 2000 and 2001; three at La Unión in 1994, 2000, and 2001; and one at Loma de Mico in 1994). We also established two control plots (at Kurinwás) in 1996 in an area of forest approximately $100 \mathrm{~km}$ outside the hurricane's path.

In the first year of the study, we located, identified, and measured the diameter $(\mathrm{DBH})$ of each tree (including palms; excluding lianas, hemiepiphytes, and stranglers) $\geq 3.2 \mathrm{~cm}$ in diameter, and tagged and mapped each tree using a coordinate system. We measured diameter $1.4 \mathrm{~m}$ from the ground, or immediately above existing buttresses and stem abnormalities, and we horizontally marked the bole of each individual to ensure that the same cross-sectional diameter was measured in successive years. We censused all plots annually in February and added new recruits to the data set in the first year they reached the minimum size-class.

BIOMASS AND ALLOMETRY.-We estimated AGBM indirectly from stem diameter $(\mathrm{DBH})$ using an allometric regression equation. Biomass equations are typically developed by harvesting entire trees or whole areas of forest, and correlating dry aboveground tree 
TABLE 1. Plot locations and summary data for four hurricane-affected sample sites and one control site (Kurinwás) established outside the path of Hurricane Joan.

\begin{tabular}{|c|c|c|c|c|c|c|c|c|c|}
\hline $\begin{array}{l}\text { Site } \\
\text { La Fonseca }\end{array}$ & $\begin{array}{c}\text { Site location }^{\mathrm{a}} \\
12^{\circ} 16^{\prime} \mathrm{N}, 83^{\circ} 58^{\prime} \mathrm{W}\end{array}$ & $\begin{array}{c}\text { Plot name } \\
\text { Molly }\end{array}$ & $\begin{array}{c}\text { Plot size (ha) } \\
0.1\end{array}$ & $\begin{array}{c}\text { Sampling years } \\
1990-1998\end{array}$ & 71 & 20 & 112 & 13 & $\begin{array}{c}\begin{array}{c}\text { Mean AGBM } \\
\text { increment } \\
(\mathrm{Mg} / \mathrm{ha} \mathrm{yr})^{\mathrm{b}}\end{array} \\
5.19(0.39)^{\mathrm{c}}\end{array}$ \\
\hline & & Luvi & 0.1 & 1990-1998 & 51 & 40 & 99 & 21 & $6.02(1.25)$ \\
\hline & & Judy & 0.1 & 1990-1998 & 153 & 19 & 189 & 13 & $4.50(3.01)$ \\
\hline & & Ernesto & 0.1 & $1990-2002$ & 50 & 0 & 109 & 2 & $4.88(1.60)$ \\
\hline & & Katrina & 0.1 & 1990-1998 & 119 & 0 & 175 & $<1$ & $7.01(1.61)$ \\
\hline & & Parc. B & 0.15 & 2001-2002 & 116 & 6 & 120 & 6 & 4.20 \\
\hline & & Rayo & 0.15 & $2000-2002$ & 110 & 1 & 116 & 1 & $2.86(1.69)$ \\
\hline Loma de Mico & $12^{\circ} 11^{\prime} \mathrm{N}, 83^{\circ} 48^{\prime} \mathrm{W}$ & Loma de Mico & 0.15 & 1994-1998 & 88 & 32 & 116 & 22 & $6.85(5.57)$ \\
\hline \multirow[t]{2}{*}{ Kurinwás } & $12^{\circ} 51^{\prime} \mathrm{N}, 83^{\circ} 46^{\prime}$ & A & 0.15 & 1996 & 345 & 0 & - & - & - \\
\hline & & B & 0.15 & 1996 & 316 & 0 & - & - & - \\
\hline
\end{tabular}

${ }^{a}$ Maps available in Vandermeer et al. (1990, 2000) and Yih et al. (1991).

${ }^{\mathrm{b}}$ Computed across all sampling years, such that the AGBM increment for a given year is computed by subtracting the AGBM of the previous year.

${ }^{\mathrm{c}}( \pm$ standard error).

biomass (AGTB) with diameter (Ovington \& Olson 1970, Edwards \& Grubb 1977, Lescure et al. 1983, Overman et al. 1994, Alves et al. 1997, Brown 1997, Laurance et al. 1997, Chave et al. 2001, Clark et al. 2001). For dicotyledons, height is not a good estimator of AGBM, because adding a third parameter to the regression frequently leads to higher correlation coefficients even if height is poorly measured (Lescure et al. 1983, Overman et al. 1994, Chave et al. 2001, Segura \& Kanninen 2005). In the case of palms, however, height is typically a better predictor of biomass accumulation than diameter (Brown 1997). Because accurate height data were not available for all years, we included palms in the analysis of all trees rather than using an alternate equation (methods follow Clark \& Clark 2000). The error associated with this inclusion is not currently known (Clark et al. 2001).

In our estimates of biomass, we used a data set published by Brown (1997) that included trees $(>4 \mathrm{~cm} \mathrm{DBH})$ from tropical wet forests in Costa Rica (101 individuals; Joyce 1989 [cited in Brown 1997]), New Guinea (41 individuals; Edwards \& Grubb 1977), and Puerto Rico (34 individuals; Ovington \& Olson 1970). We chose the data set based on its relevance to the forest ecosystem of the Atlantic zone of Nicaragua in terms of climate, soil, and vegetation characteristics. We used the data to fit a correlation between $\mathrm{DBH}$ and AGTB, of the form:

$\ln (\mathrm{AGTB}[\mathrm{kg}])=\alpha+\beta * \ln (\mathrm{DBH}[\mathrm{cm}])$

such that $\alpha=-2.52 \pm 0.11$ (SE), $\beta=2.51 \pm 0.03$, and $R^{2}>0.97$ (JMP 2002).
Our study differs from previous studies of AGBM accumulation with respect to the calculation of biomass increment. Annual $\mathrm{DBH}$ measurements remove the need to use diameter size classes when measuring biomass change over time (Brown 1997, Clark et al. 2001). The biomass of each tree is thus followed individually from year to year. Under this measurement scenario, the ingrowth and mortality of individual trees are recorded annually, and there is no need to use diameter size classes to account for it (see Clark et al. 2001). Although our minimum size class included individuals that were up to $0.8 \mathrm{~cm}$ smaller in diameter than those represented by the Brown (1997) data set, the importance of these individuals in AGBM estimates was nominal ( $<0.9 \%$ in 2002).

\section{RESULTS}

Live AGBM in two plots undamaged by the hurricane (total area $0.3 \mathrm{ha})$ averaged $331( \pm 15) \mathrm{Mg} / \mathrm{ha}$, and stem density and relative AGBM contribution were skewed to the smallest and largest size classes, respectively (Fig. 1). Individuals $3.2-10 \mathrm{~cm}$ in diameter constituted more than 89 percent of all stems (1203 \pm 117 stems/ha), but accounted for only 2.5 percent of AGBM ( $8 \pm 1 \mathrm{Mg} / \mathrm{ha})$. In contrast, seven trees $>70 \mathrm{~cm}$ in diameter made up only 1.4 percent of stems ( $23 \pm 3$ stems/ha) but totaled 45 percent of AGBM (148 $\pm 9 \mathrm{Mg} / \mathrm{ha})$.

In the six hurricane-damaged plots, AGBM was quite variable, ranging from 26 to $153 \mathrm{Mg} / \mathrm{ha}$, (mean $78 \pm 15 \mathrm{Mg} / \mathrm{ha}$ ). The combined plot area $(0.6 \mathrm{ha})$ included only four trees $>50 \mathrm{~cm} \mathrm{DBH}$, 

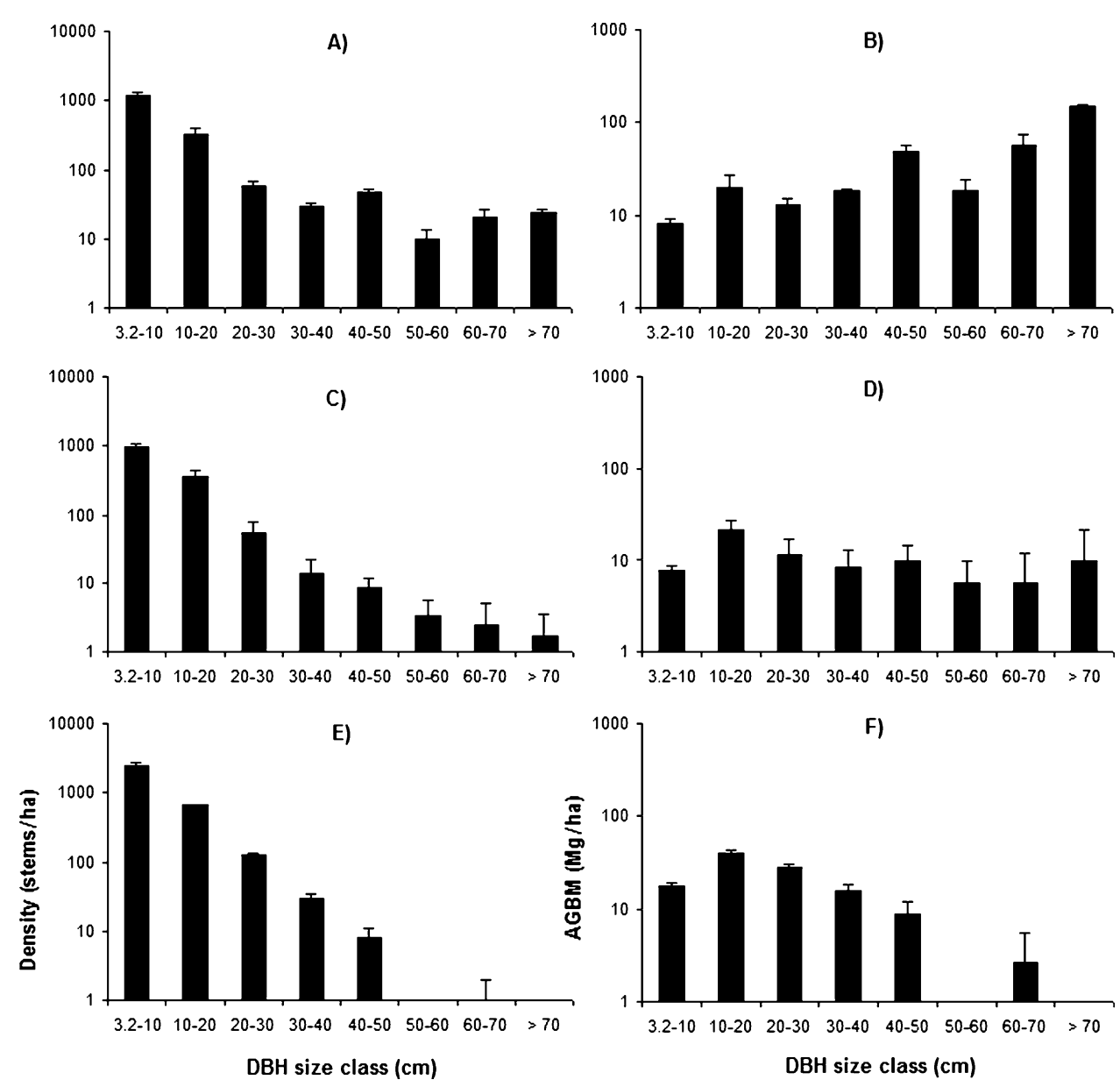

FIGURE 1. Relative contribution of $10 \mathrm{~cm}$ size classes (minimum $3.2 \mathrm{~cm}$ ) to stem density (stems $/ \mathrm{ha}$ ) and aboveground biomass (AGBM; Mg/ha). (A) Mean stem density and (B) AGBM of the two control plots (1996). (C) Mean stem density and (D) AGBM for the first six hurricane-affected plots (1990). (E) Mean stem density and (F) AGBM for eight remaining plots in the most recent measurement year (2002).

and only one tree $>70 \mathrm{~cm}$. This single tree (Pterocarpus officinalis), found at La Fonseca "Judy," accounted for 12 percent of mean AGBM $(10 \pm 11 \mathrm{Mg} / \mathrm{ha})$. Overall, the relative contribution of the larger size classes $(>30 \mathrm{~cm})$ to both stem density and AGBM was less than in forests unaffected by the hurricane (Fig. 1). The relative density of the smallest size class $(3.2-10 \mathrm{~cm} \mathrm{DBH})$ in hurricanedamaged plots was also less than for the unaffected forest $(68 \%$ or $953 \pm 116$ stems/ha), but the relative contribution to AGBM was greater $(9 \%$ or $8 \pm 1 \mathrm{Mg} / \mathrm{ha})$. However, the above effects of the hurricane on density and AGBM were not significant (two-way analysis of variance using size class, hurricane treatment, and an interaction term; JMP 2002).

AGBM rose steadily for each plot across years following the hurricane impact (Fig. 2), though accumulation was highly variable across all plots and years, ranging from -8 to $22 \mathrm{Mg} / \mathrm{ha} / \mathrm{yr}$. Accumulation rates for each plot averaged across years are reported in Table 1. To examine changes in AGBM increment, we calculated the mean AGBM accumulation rate for each year (Fig. 3). The overall AGBM accumulation rate, averaged across $11 \mathrm{yr}$ of increment data was $5.36( \pm 0.74) \mathrm{Mg} /$ ha yr. Only in 1998 and 1999 did this rate deviate noticeably, with mean accumulations of only 1.37 and $0.95 \mathrm{Mg} / \mathrm{ha}$, respectively (Fig. 3). Because the plots were sampled in February, these two periods coincide with the 1997-1998 ENSO, which caused higher temperatures and lower precipitation over a significant region of the Central American isthmus. Five of the eight active plots had to be abandoned in 1999 as a result of ENSO-related fires and agricultural encroachment, and of the three that remained, only one (La Unión A) did not show a negative AGBM accumulation rate in either 1998 or 1999.

Restricting our data to two plots that survived the entire length of the study, AGBM rate differed little from the overall mean (5.49 $\pm 1.29 \mathrm{Mg} / \mathrm{ha} / \mathrm{yr}$ ). We also noted minimal differences when considering the first $7 \mathrm{yr}$ of increment values for the six original plots $(5.58 \pm 0.84 \mathrm{Mg} / \mathrm{ha} / \mathrm{yr})$, four plots in which the palm contribution to AGBM was $>10$ percent $(5.49 \pm 1.07 \mathrm{Mg} / \mathrm{ha} / \mathrm{yr})$, and eight plots in which the palm contribution was $<10$ percent $(5.37 \pm$ $1.07 \mathrm{Mg} / \mathrm{ha} / \mathrm{yr})$.

In 2002, $14 \mathrm{yr}$ after the hurricane impact, AGBM in hurricaneaffected plots ranged from 99 to $128 \mathrm{Mg} / \mathrm{ha}$ (mean: $113 \pm 4$ $\mathrm{Mg} / \mathrm{ha}$ ). However, only two of the original six plots were represented 


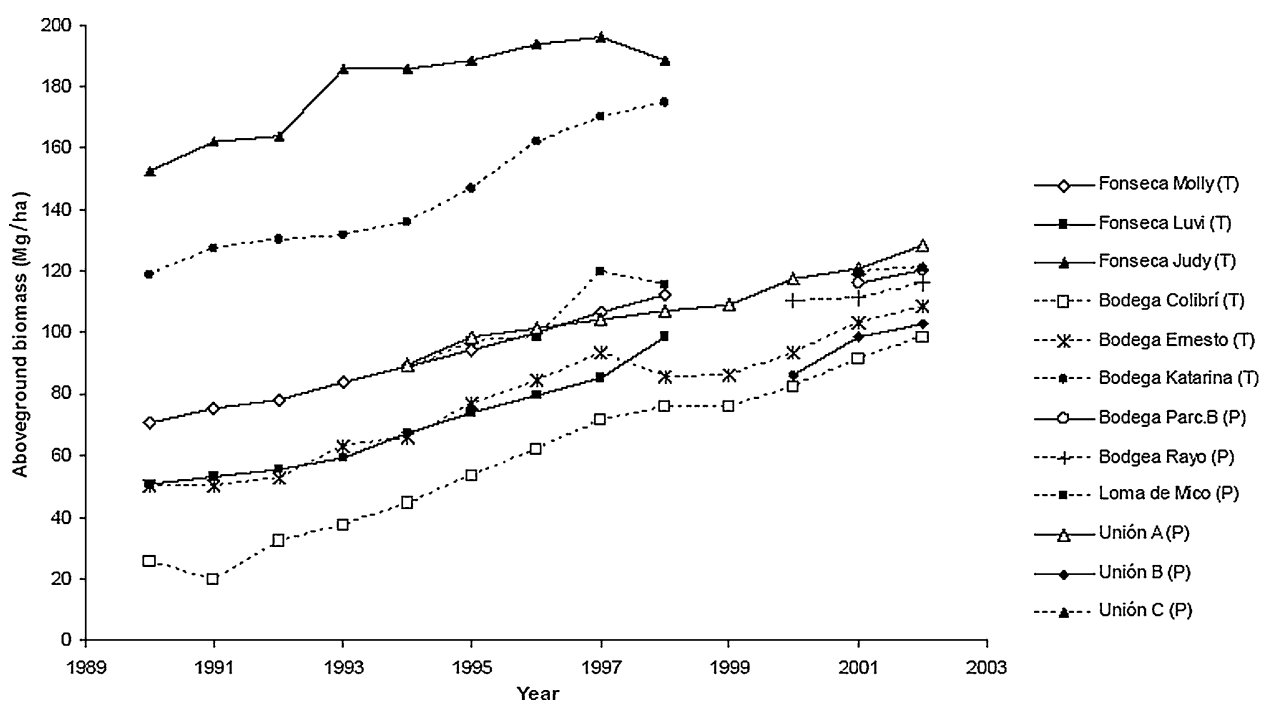

FIGURE 2. Aboveground biomass (AGBM; Mg/ha) for each plot in each year following disturbance by Hurricane Joan. Plots denoted as $(\mathrm{T})$ are $100 \times 10 \mathrm{~m}$; those marked $(\mathrm{P})$ are $50 \times 30 \mathrm{~m}$. Primary forest AGBM was estimated at $331 \mathrm{Mg} / \mathrm{ha}$.

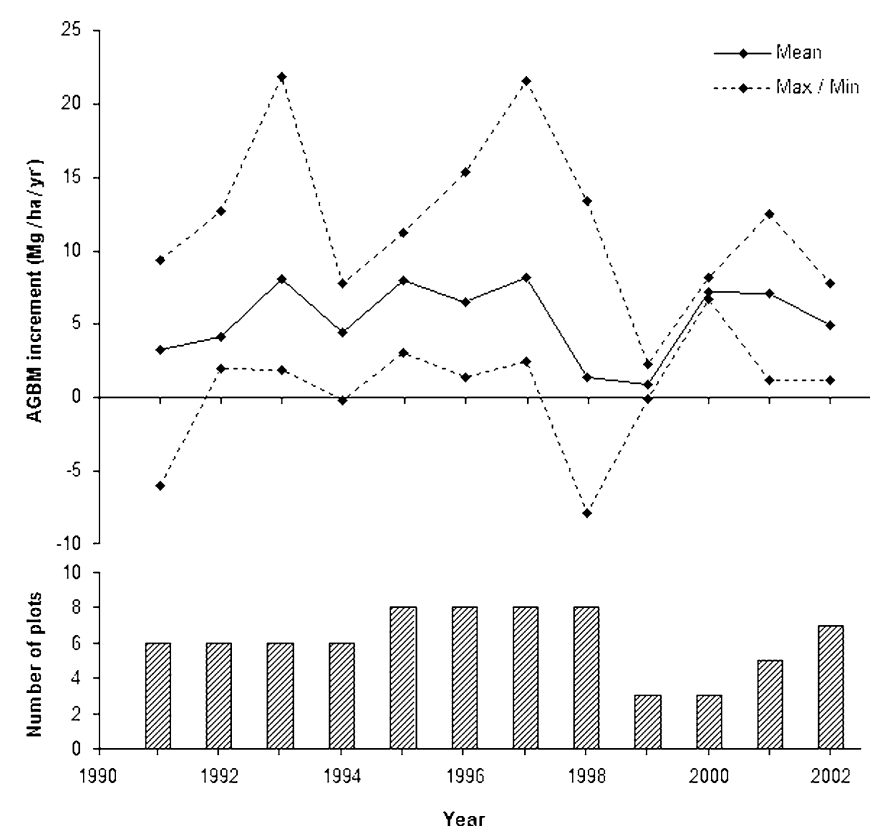

FIGURE 3. Mean annual aboveground biomass increment calculated as the change from the previous year to the current year for all 12 plots. Dashed lines indicate associated absolute maximum and minimum values for each year. The tightening of the range for the year 1999 is caused by the loss of five of eight active plots, as indicated by the bar graph.

in 2002, due to losses to agriculture and fire (Table 1). At the time of abandonment, two plots had reached or exceeded 50 percent of the primary forest AGBM (Fonseca "Judy" in 1998 and Bodega "Katerina" in 1998). Overall stem density in the remaining plots was almost double that of the undisturbed forest (3282 vs. 1720 stems/ha). The relative AGBM contribution of stems $3.2-10 \mathrm{~cm}$ DBH was 15 percent $(18 \pm 1 \mathrm{Mg} / \mathrm{ha})$, and stems $<20 \mathrm{~cm} \mathrm{DBH}$ made up more than 50 percent of mean AGBM $(58 \pm 2 \mathrm{Mg} / \mathrm{ha})$. Only one tree $>50 \mathrm{~cm} \mathrm{DBH}$ was found in the combined plot area (0.95 ha), accounting for just 2 percent of mean AGBM (3 \pm 3 $\mathrm{Mg} / \mathrm{ha})$.

\section{DISCUSSION}

ASSUMPTIONS AND ERROR.- - The estimates of AGBM rely on several assumptions, and thus we urge caution in the interpretation of the results. The most important of these assumptions is that the allometric regression equation used is a good match for the forest ecosystem of the Atlantic lowlands of Nicaragua. Each of the three sites included in the harvest data set were representative of tropical wet forests in general (Brown 1997). Furthermore, the Costa Rican data (101 of 176 individuals) were collected within $20 \mathrm{~km}$ of the $\mathrm{La}$ Selva Biological Station, approximately $200 \mathrm{~km}$ south of Bluefields. The climate at La Selva is similar to the region around Bluefields, receiving approximately $4000 \mathrm{~mm}$ of rainfall per year with virtually no dry season, and a mean annual temperature of approximately $26^{\circ} \mathrm{C}$ (McDade \& Hartshorn 1994). Blair (2002) collected extensive soil data for many of the sites used in this study, noting that available phosphorus, potassium, and carbon were within the range obtained at La Selva, though nitrogen was slightly higher than the mean for lowland forests in Costa Rica (Sollins et al. 1994). Compared to other mature Neotropical forests, AGBM of the nonhurricanedamaged forest $(331 \pm 15 \mathrm{Mg} / \mathrm{ha})$ was within the range found by DeWalt and Chave (2004; 175-466 Mg/ha, excluding lianas), and 
was within the standard error found on ultisols at La Selva $(256 \pm$ $80 \mathrm{Mg} / \mathrm{ha}$ ).

Clark and Clark (2000) noted, however, that even within a life zone the equation used to calculate AGBM might be a source of error. Allometric relationships between diameter and AGBM of individual trees are likely to vary considerably within a given climactic regime, and without harvesting local trees or collecting specific gravity measurements there is no way to correct for possible error (Segura \& Kanninen 2005). Another problem inherent in the use of allometric equations is the tendency for harvesters to use predominantly healthy, robust individuals, and this was certainly the case for the Costa Rican data (Clark \& Clark 2000). Application of the equation to damaged individuals will result in an overestimation of their biomass because crown damage is not evident from diameter measurements (Clark \& Clark 2000). This problem may be exacerbated in our study because large individuals that survived the hurricane event incurred a significant amount of canopy damage (Yih et al. 1991). In addition, the AGBM increment for such individuals could be underestimated if they redirected photosynthate toward rebuilding their crowns.

The plots used were small $(0.1-0.15 \mathrm{ha})$ and were insufficient to capture the spatial distribution of large trees that dominate biomass estimates. However, the damage caused by Hurricane Joan removed virtually all the large trees from the sample area, increasing the importance of smaller trees in biomass estimates (Fig. 1). Furthermore, although the stand-level equation used was not intended for application to palms, palm contribution to AGBM was limited (Table 1), and plots with substantial palm densities did not show markedly different AGBM accumulation rates from either the overall mean or plots lacking palms.

Finally, we included only AGBM of living trees in the analysis, and the exclusion of other growth forms, such as lianas, is certainly an underestimation. Although lianas are important in canopy regeneration (Schnitzer et al. 2000), they do not typically represent a significant portion of AGBM (Putz 1983), especially in tropical wet forests, where they have been found to be relatively uncommon (Gentry 1991, Mascaro et al. 2004).

Biomass aCCUMUlation.-Hurricanes tend to destroy forest canopies in a patchy, heterogeneous pattern across the landscape (Brokaw \& Grear 1991, Lugo 2000); however, the damage from Hurricane Joan was much more homogenous than previously documented storms, such as Hurricane Hugo (Yih et al. 1991). The finely dissected terrain of Puerto Rico probably protected whole areas of forest from damage associated with high wind velocities (Scantena et al. 1996). In contrast, the forest damaged by Hurricane Joan occupies the coastal plane, where large breaks in topography are virtually absent. Without such physical barriers, patches of primary forest were not retained, and canopy destruction was fairly regular (Vandermeer et al. 1990, Yih et al. 1991). Although this pattern was not expressed in the variability of initial AGBM values $(26-153 \mathrm{Mg} / \mathrm{ha}$ ), individual plot sizes were too small to accurately characterize the spatial distribution of large trees. However, structural damage favored the advanced regeneration at the expense of the larger size classes (Fig. 1), and was consistent with the ten- dency of wind disturbances to damage large, overstory trees while leaving the understory intact (see, e.g., Everham \& Brokaw 1996). The mean ABGM increment $(5.36 \pm 0.74 \mathrm{Mg} / \mathrm{ha} / \mathrm{yr})$, while within the range of secondary forests in general (Brown \& Lugo 1990), is lower than other rates reported for neotropical wet and seasonally wet forests. Lower, and in some cases negative, AGBM accumulation for 1998 and 1999 is the result of reduced tree growth and increased tree mortality, probably related to the 1997-1998 ENSO event. Chazdon et al. (2005) followed tree mortality from 1997 to 2003 in secondary forest sites at La Selva, and observed higher mortality in all size-classes during the 1997-1998 ENSO period. Mortality was 1.9 times higher for trees $\geq 10 \mathrm{~cm} \mathrm{DBH}$, the size-class that would confer the greatest affect on AGBM, and was probably caused by reduced dry-season rainfall. In addition to precipitation effects, higher mean annual temperatures associated with ENSO periods have been shown to negatively affect the rate of photosynthesis in tropical trees (Clark et al. 2003).

The most detailed investigations of tropical AGBM accumulation following hurricane disturbances come from the Luquillo Long-Term Ecological Research site on Puerto Rico. After 5 yr of regeneration following the landfall of Hurricane Hugo in 1989, Scatena et al. (1996) reported an AGBM accumulation of 16.3 $\mathrm{Mg} / \mathrm{ha} / \mathrm{yr}$ in the Bisley watershed, a subtropical wet forest receiving between 3000 and $4000 \mathrm{~mm}$ of rainfall each year (Scatena et al. 1993). Initial estimates of surviving AGBM averaged $78( \pm 15)$ $\mathrm{Mg} / \mathrm{ha}$ in Nicaragua, compared to $113( \pm 25) \mathrm{Mg} / \mathrm{ha}$ for Bisley, and this represents a more significant loss from the estimated primary forest value for the Nicaraguan forest ( $76 \%$ vs. $50 \%)$. Regeneration was nearly three times more rapid for the Bisley watershed, and the species-level processes operating after the two storms were quite different. In the case of Hurricane Joan, nearly all the species present prior to the storm regenerated directly via resprouting, or as seedlings or saplings that had established prior to the disturbance (Boucher 1990; Vandermeer et al. 1990, 1995, 1996, 2000; Yih et al. 1991). Following Hurricane Hugo, however, regeneration was dominated by pioneer species (i.e., Cecropia schreberiana, Psychotria berteriana, and Guarea glabra) that had been less abundant prior to the disturbance (Scatena $e t$ al. 1996). In fact, 83 percent of the AGBM accumulation $(14.5 \mathrm{Mg} / \mathrm{ha} / \mathrm{yr})$ measured was due to postdisturbance proliferation of pioneers, rather than the growth or sprouting of surviving individuals.

AGBM accumulation rates for agricultural succession also appear to be higher than those following Hurricane Joan. A relatively more massive $(401 \mathrm{Mg} / \mathrm{ha})$ seasonal rainforest $(2300 \mathrm{~mm} / \mathrm{yr})$ in the western Brazilian Amazon was estimated to regenerate at 6.6-8.7 $\mathrm{Mg} / \mathrm{ha} / \mathrm{yr}$ following low intensity agricultural activity, based on a chronosequence of stands between 2 and $18 \mathrm{yr}$ of age (Alves et al. 1997). After $18 \mathrm{yr}$ of regeneration, AGBM ranged from 40 to 60 percent of the primary forest estimate, depending on the allometric regression equation used. While two plots established in the wake of Joan had reached 50 percent of the estimated primary forest value prior to abandonment, each of these had a standing AGBM of more than $100 \mathrm{Mg} /$ ha immediately following the disturbance. The initial AGBM reported by Alves et al. (1997) was much closer to 0 (10 $\mathrm{Mg} / \mathrm{ha}$ after $2 \mathrm{yr}$ ). In a review of more than 20 studies, AGBM 
accumulation following agricultural and pasture abandonment averaged 6.2 Mg/ha/yr (Silver et al. 2000). Rates of accumulation were more significantly affected by previous land use than by life zone, with pasture lands regenerating somewhat slower than agricultural fields, and all rates slowing after a period of $20 \mathrm{yr}$. Furthermore, using an empirical model based on soil texture and climate data (Johnson et al. 2000), Zarin et al. (2001) predicted a regional AGBM accumulation rate of $7.6 \mathrm{Mg} / \mathrm{ha} / \mathrm{yr}$ for Amazonian secondary forests on nonsandy soils similar to those found in the Bluefields region.

The comparatively slow rate of regeneration following Hurricane Joan could be attributed to higher initial AGBM immediately after the disturbance (relative to abandoned agricultural lands), effectively starting succession past the most rapid accumulation rates. However, this would not explain the difference in AGBM accumulation between forests following Hurricanes Hugo in Puerto Rico and Joan in Nicaragua.

We suggest that the fundamental differences in succession that contrast the regeneration following Hurricane Hugo and Hurricane Joan also set the latter apart from regeneration following agricultural activity. In a species-level analysis of several abandoned agricultural fields near the Bodega and Fonseca transects, Boucher et al. (2001) found that while postagricultural forests were floristically distinct from primary forests, prehurricane and posthurricane forests were relatively similar in composition. We further suggest that the high abundance of "late-successional" species with relatively slower absolute growth rates was largely responsible for the lower rate of AGBM accumulation estimated for this tropical wet forest recovering from the impact of Hurricane Joan. Biomass production following disturbance has been shown to vary with respect to stand age, growing season length and temperature, soil moisture and nutrient availability, and disturbance size and intensity (Johnson et al. 2000), and to this list we would add and emphasize the successional composition of the forest community.

The mechanism for this successional contrast lies in the nature of canopy damage caused by Hurricane Joan. The destruction of the forest canopy over such a wide area was particularly devastating for large trees and left very few seed trees. This severely limited seed dispersal and allowed late-successional survivors to take advantage of resources for which they might otherwise be outcompeted. In contrast, persistent patches of primary forest in Puerto Rico following Hurricane Hugo appear to have provided a seed source for the overwhelming dominance (83\%) of newly recruited individuals found in regenerating areas of forest (Scatena et al. 1996).

HURRICANE JOAN AND CLIMATE CHANGE.--In the Luquillo Experimental Forest, the 60-yr hurricane return time was shown to be somewhat longer than the recovery time for biomass (Scatena \& Larsen 1991, Scatena 1995, Scatena et al. 1996), suggesting a synchrony with the disturbance (Lugo \& Scatena 1996). Based on our initial estimates of AGBM recovery following Hurricane Joan, it is difficult to estimate the regeneration time required for the damaged forest to return to primary forest biomass levels. However, using mean AGBM values prior to the 1997-1998 ENSO, we estimated recovery times ranging from 70 to $200 \mathrm{yr}$ for an accumulation of 90 percent of the estimated primary forest AGBM of $331 \mathrm{Mg} / \mathrm{ha}$ (Schumacher growth function, Schumacher 1939; Chapman-Richards function, Richards 1959, Chapman 1961; JMP 2002). This estimate does not allow us to predict whether these sites will quantitatively recover within the 100 -yr return time estimated for hurricanes of Joan's intensity. However, we are continuing to follow AGBM reorganization and accumulation in the region surrounding Bluefields to improve our calculations of regeneration times.

While several studies have suggested that anthropogenic climate forcing might result in a tightening of hurricane return intervals for the Atlantic (reviewed in Dale et al. 2001), empirical evidence of this connection is lacking (Easterling et al. 2000). However, Goldenberg et al. (2001) analyzed multidecadal variation in hurricane frequency and indicated that hurricane seasons from 1995 to 2000 represent a turn toward a $10-40$-yr period of heavy activity, particularly for the Caribbean. This trend cannot be explained entirely by anthropogenic forcing, nor can forcing be discounted as a contributing factor (Goldenberg et al. 2001). Lugo (2000) detailed the ecosystem-level responses associated with increased hurricane frequency and intensity, and we will not echo them here except to say that AGBM would be reduced and limited because growth would be interrupted with greater frequency or intensity. The area of primary forest destroyed by Hurricane Joan was more than 15 percent of the total forested land area in Nicaragua, and with the relatively slow rate of regeneration reported here, any tightening in disturbance interval could reduce the capacity of the AGBM to store carbon.

\section{ACKNOWLEDGMENTS}

We thank D. Ellsworth and D. A. Clark, who graciously facilitated our understanding of plant allometry and biomass equations, and everyone in the Perfecto/Vandermeer labs for their efforts in data collection. Comments by R. Chazdon, D. B. Clark, W. Carson, S. Schnitzer, M. Santana, and T. Taneva, as well as thoughtful reviews by S. Van Bloem, D. Zarin, F. Hughes, and one anonymous referee substantially improved this manuscript. We also thank R. DeYoung, D. Infante, R. Bierbaum, and all of the SNRE 499 students for their investment in the honors thesis program. This study was supported by NSF grants DSR-891768, DEB-9524061, and DEB-0235761 to J. Vandermeer, and by NSF grant DEB-0135350 and funding from the Whitaker Foundation to D. H. Boucher.

\section{LITERATURE CITED}

Alves, D. S., J. V. Soares, S. Amaral, E. M. K. Mello, S. A. S. Almeida, O. F. DA SILVA, AND A. M. SilveIRA. 1997. Biomass of primary and secondary vegetation in Rondonia, Western Brazilian Amazon. Glob. Change Biol. 3: 451-461.

Belt, T. 1888. The naturalist in Nicaragua, 2nd edn. Ballantyne Press, London, UK.

BLAIR, B. C. 2002. Soil nutrient heterogeneity and root foraging in a Nicaraguan rainforest: Patterns, processes and potential implications for competitive 
dynamics. Ph.D. dissertation. The University of Michigan, Ann Arbor, Michigan.

Boose, E. R., D. R. Foster, AND M. Fluet. 1994. Hurricane impacts to tropical and temperate forest landscapes. Ecol. Monogr. 64: 369-400.

BOUCHER, D. H. 1990. Growing back after hurricanes. Bioscience 40: 163-166.

—. 1992. En la Costa, un huracán cada siglo? Wani 12: 32-34.

- J. J. H. Vandermeer, I. Granzow de la Cerda, M. A. Mallona, I. PerFECTO, AND N. ZAMORA. 2001. Post-agriculture versus post-hurricane succession in southeastern Nicaraguan rain forest. Plant Ecol. 156: 131137.

Breshears, D. D., and C. D. Allen. 2002. The importance of rapid, disturbance-induced losses in carbon management and sequestration. Glob. Ecol. Biogeogr. 11: 1-5.

BROKAW, N. V. L., AND J. S. GREAR. 1991. Forest structure before and after Hurricane Hugo at three elevations in the Luquillo Mountains, Puerto Rico. Biotropica 23: 386-392.

—, AND L. R. WALKER. 1991. Summary of the effects of Caribbean hurricanes on vegetation. Biotropica 23: 442-447.

BROWN, S. 1997. Estimating biomass and biomass change of tropical forests: A primer. Forestry Paper 134. Food and Agriculture Organization, Rome, Italy.

—, AND A. LUGO. 1982. The storage and production of organic matter in tropical forests and their role in the global carbon cycle. Biotropica 14: 161-187.

—, AND A. E. LugO. 1990. Tropical secondary forests. J. Trop. Ecol. 6: 1-32.

Cairns, M. A., P. K. Haggerty, R. Alvarez, B. H. J. De Jong, and I. Olmsted. 2000. Tropical Mexico's recent land-use change: A region's contribution to the global carbon cycle. Ecol. Appl. 10: 1426-1441.

Chapman, D. G. 1961. Statistical problems in population dynamics. In Proceedings of the fourth Berkeley symposium on mathematical statistics and probability, pp. 153-168. University of California Press, Berkeley, California.

Chave, J., B. Riera, and M.-A. Dubios. 2001. Estimation of biomass in a neotropical forest of French Guiana: Spatial and temporal variability. J. Trop. Ecol. 17: 79-96.

Chazdon, R. L., A. R. Brenes, and B. V. Alvarado. 2005. Effects of climate and stand age on annual tree dynamics in tropical second-growth rain forests. Ecology 86: 1808-1815.

Clark, D. A., S. Brown, D. W. Kicklighter, J. Q. Chambers, J. R. ThomLINSON, AND J. NI. 2001. Measuring net primary production in forests: Concepts and field methods. Ecol. Appl. 11: 356-370.

—, S. C. Piper, C. D. Keeling, and D. B. Clark. 2003. Tropical rain forest tree growth and atmospheric carbon dynamics linked to interannual temperature variation during 1984-2000. Proc. Natl. Acad. Sci. USA 100: 5852-5857.

Clark, D. B., and D. A. Clark. 2000. Landscape-scale variation in forest structure and biomass in a tropical rain forest. For. Ecol. Manage. 137: 185-198.

Dale, V. H., L. A. Joyce, S. McNulty, R. P. Neilson, M. P. Ayres, M. D. Flannigan, P. J. Hanson, L. C. Irland, A. E. Lugo, C. J. Peterson, D. Simberloff, F. J. Swanson, B. J. Stocks, and B. M. Wotton. 2001. Climate change and forest disturbances. Bioscience 51: 723-734.

DeWalt, S. J., and J. Chave. 2004. Structure and biomass of four lowland Neotropical forests. Biotropica 36: 7-19.

Easterling, D. R., G. A. Meehl, C. Parmesan, S. A. Changnon, T. R. Karl,
AND L. O. MEARNS. 2000. Climate extremes: Observations, modeling, and impacts. Science 289: 2068-2074.

EDWARDS, P. J., AND P. J. GRUBb. 1977. Studies of mineral cycling in a montane rain forest in New Guinea. J. Ecol. 65: 943-969.

Emanuel, K. A. 1987. The dependence of hurricane frequency on climate. Nature 326: 483-485.

Everham, E. E., AND N. V. L. BROKAW 1996. Forest damage and recovery from catastrophic wind. Bot. Rev. 62: 113-185.

FEARNSide, P. M., AND W. M. GuimaraEs. 1996. Carbon uptake by secondary forests in Brazilian Amazonia. For. Ecol. Manage. 80: 35-46.

Gentry, A. H. 1991. The distribution and evolution of climbing plants. In F. E. Putz and H. A. Mooney (Eds.). The biology of vines, pp. 3-49. Cambridge University Press, Cambridge, UK.

Goldenberg, S. B., C. W. Landsea, A. M. Mestas-Nuñez, and W. M. Gray. 2001. The recent increase in Atlantic hurricane activity: Causes and implications. Science 293: 474-479.

Granzow de la Cerda, I., N. Zamora, J. Vandermeer, and D. Boucher. 1997. Diversidad de especies arbóreas en el bosque tropical húmedo del Caribe nicarágüense siete años después del huracán Juana. Rev. Biol. Trop. 45: 1409-1419.

GrAY, W. M. 1990. Strong association between West African rainfall and U.S. landfall of intense hurricanes. Science 249: 1251-1256.

Hoffert, M. I., K. Caldeira, G. Benford, D. R. Criswell, C. Green, H. Herzog, A. K. Jain, H. S. Kheshgi, K. S. Lackner, J. S. Lewis, H. D. Lightfoot, W. Manheimer, J. C. Mankins, M. E. Mauel, L. J. Perkins, M. E. Schlesinger, T. Volk, And T. M. L. Wigley. 2002. Advanced technology paths to global climate stability: Energy for a greenhouse planet. Science 298: 981-987.

Holdridge, L. R., W. C. Grenke, W. H. Hatheway, T. Liang, and J. A. TosI, JR. 1971. Forest environments in tropical life zones. Pergamon Press, New York.

Hollowell, V. C. (Ed.). 2001. Flora de Nicaragua. Missouri Botanical Garden Press, St. Louis, Missouri.

Houghton, R. A., D. L. Skole, C. A. Nobre, J. L. Hackler, K. T. LaWrence, AND W. H. CHOMENTOwski. 2000. Annual fluxes of carbon from deforestation and regrowth in the Brazilian Amazon. Nature 403: 301-304.

Hughes, R. F., J. B. KaufFman, AND V. J. Jaramillo. 1999. Biomass, carbon, and nutrient dynamics of secondary forests in a humid tropical region of Mexico. Ecology 80: 1892-1907.

INCER, J. (Ed.). 1973. Geografia ilustrada de Nicaragua. Editorial Recalde, Managua.

Johnson, C. M., D. J. ZARIN, AND A. H. Johnson. 2000. Post-disturbance aboveground biomass accumulation in global secondary forests. Ecology 81: 1395-1401.

JMP. 2002. Version 5. SAS Institute Inc., Cary, North Carolina.

Laurance, W. F., S. G. Laurance, L. V. Ferreira, J. M. Rankin-De-Merona, C. GASCON, AND T. E. Lovejoy. 1997. Biomass collapse in Amazonian forest fragments. Science 278: 1117-1118.

Lescure, J. -P., H. Puig, B. Riera, D. Leclerc, A. Beekman, and A. Beneteau. 1983. La phytomasse epigee d'une foret dense en Guyana Francaise. Acta Oecol. 4: 237-251.

Lugo, A. E. 2000. Effects and outcomes of Caribbean hurricanes in a climate change scenario. Sci. Total Environ. 262: 243-251.

— - AND F. N. SCATENA. 1996. Background and catastrophic tree mortality in tropical moist, wet, and rain forests. Biotropica 28: 585-599. 
Mascaro, J., S. A. Schnitzer, AND W. P. Carson. 2004. Liana diversity, abundance, and mortality, in a tropical wet forest in Costa Rica. For. Ecol. Manage. 190: 3-14.

McDade, L. A., And G. S. Hartshorn. 1994. La Selva Biological Station. In L. A. McDade, K. S. Bawa, H. A. Hespenheide, and G. S. Harthsorn (Eds.). La Selva: Ecology and natural history of a neotropical rainforest, pp. 6-14. The University of Chicago Press, Chicago, Illinois.

MCNuLTY, S. G. 2002. Hurricane impacts on US forest carbon sequestration. Environ. Pollut. 116: S17-S24.

Ovington, J. D., AND J. S. Olson. 1970. Biomass and chemical content of El Verge lower montane rain forest plants. In H. T. Odum and R. F. Pigeon (Eds.). A tropical rain forest: A study of irradiation and ecology at $\mathrm{El}$ Verge, Puerto Rico, Vol. TID 24270, pp. H53-H77. Clearinghouse for Federal Scientific and Technical Information, Springfield, Virginia.

Overman, J. P. M., H. J. L. WitTe, and J. G. SaldarRiaga. 1994. Evaluation of regression models for above-ground biomass determination in Amazon rainforest. J. Trop. Ecol. 10: 207-218.

PuTZ, F. E. 1983. Liana biomass and leaf area of a 'terra firme' forest in the Rio Negro basin, Venezuela. Biotropica 15: 185-189.

Richards, F. J. 1959. A flexible growth function for empirical use. J. Exp. Bot. 10: 290-300.

RUDEL, T. K. 2001. Sequestering carbon in tropical forests: Experiments, policy implications, and climate change. Soc. Nat. Resour. 14: 525-531.

SCATENA, F. N. 1995. Relative scales of time and effectiveness of watershed processes in a tropical montane rain forest of Puerto Rico. In Natural and anthropogenic influences in fluvial geomorphology, pp. 103-111. Geophysical Monograph 89. American Geophysical Union, Washington, DC

—, ANd M. C. LarSen. 1991. Physical aspects of Hurricane Hugo in Puerto Rico. Biotropica 23: 317-323.

— S. Moya, C. Estrada, and J. D. Chinea. 1996. The first five years in the reorganization of aboveground biomass and nutrient use following Hurricane Hugo in the Bisley Experimental Watersheds, Luquillo Experimental Forest, Puerto Rico. Biotropica 28: 424-440.

—, W. Silver, T. SicCama, A. Johnson, And M. J. SAnChez. 1993. Biomass and nutrient content of the Bisley Experimental Watersheds, Luquillo Experimental Forest, Puerto Rico, before and after Hurricane Hugo, 1989. Biotropica 25: 15-27.

SChnitzer, S. A., J. W. Dalling, AND W. Carson. 2000. The impact of lianas on tree regeneration in tropical forest canopy gaps: Evidence for an alternative pathway of gap-phase regeneration. J. Ecol. 88: 655-666.

SCHUMACHER, F. X., 1939. A new growth curve and its application to timber yield studies. J. For. 37: 819-920.

SEgURA, M., AND M. KANNINEN. 2005. Allometric models for tree volume and total aboveground biomass in a tropical humid forest in Costa Rica. Biotropica 37: 2-8.
Silver, W. L., R. Ostertag, AND A. E. Lugo. 2000. The potential for carbon sequestration through reforestation of abandoned tropical agricultural and pasture lands. Restor. Ecol. 8: 394-407.

Sollins, P., F. Sancho M., R. Mata Ch., and R. L. Sanford, JR. 1994. Soils and soil process research. In L. A. McDade, K. S. Bawa, H. A. Hespenheide, and G. S. Harthsorn (Eds.). La Selva: Ecology and natural history of a neotropical rainforest, pp. 34-53 The University of Chicago Press, Chicago, Illinois.

Vandermeer, J., D. Boucher, I. Perfecto, and I. Granzow de la Cerda. 1996. A theory of disturbance and species diversity: Evidence from Nicaragua after Hurricane Joan. Biotropica 28: 600-613.

— - AND I. GRANZOW DE LA CERDA. 2004. Height dynamics of the thinning canopy of a tropical rain forest: 14 years of succession in a post-hurricane forest in Nicaragua. For. Ecol. Manage. 199: 125-135.

— AND I. PERfECTO. 1995. Breakfast of biodiversity: The truth about rainforest destruction. The Institute for Food and Development Policy, Oakland, California.

- - i. Granzow de la Cerda, D. Boucher, I. Perfecto, and J. Ruiz. 2000. Hurricane disturbance and tropical tree species diversity. Science 290: 788-791.

—, M. Mallona, D. Boucher, I. Perfecto, and K. Yih. 1995. Three years of ingrowth following catastrophic hurricane damage on the Caribbean coast of Nicaragua: Evidence in support of the direct regeneration hypothesis. J. Trop. Ecol. 11: 465-471.

—, N. Zamora, K. Yih, AND D. BouCher. 1990. Regeneracíon inicial en una selva tropical de la coasta caribeña de Nicaragua después del huracán Juana. Rev. Biol. Trop. (Costa Rica) 38: 347-359.

VitouseK, P. M. 1991. Can planted forests counteract increasing atmospheric carbon dioxide? J. Environ. Qual. 20: 348-354.

Walker, L. R., D. J. Lodge, N. V. L. BrokaW, and R. B. Waide. 1991. An introduction to hurricanes in the Caribbean. Biotropica 23: 313-316.

Walsh, K., And A. B. PITTOCK. 1998. Potential changes in tropical storms, hurricanes, and extreme rainfall events as a result of climate change. Clim. Change 39: 199-213.

Yih, K., D. H. Boucher, J. H. Vandermeer, and N. Zamora. 1991. Recovery of the rain forest in southeastern Nicaragua after destruction by Hurricane Joan. Biotropica 23: 106-113.

Zarin, D. J., M. J. Ducey, J. M. Tucker, and W. A. Salas. 2001. Potential biomass accumulation in Amazonian regrowth forests. Ecosystems 4: 658-668.

Zimmerman, J. K., T. M. Aide, M. Rosario, M. Serrano, and L. Herrera. 1995. Effects of land management and a recent hurricane on forest structure and composition in the Luquillo Experimental Forest, Puerto Rico. For. Ecol. Manage. 77: 65-76.

—, M. R. Willig, L. R. WalKer, AND W. L. Silver. 1996. Introduction: Disturbance and Caribbean ecosystems. Biotropica 28: 414-423. 